\title{
Late Pleistocene fossil hominid tracks on the beaches of Claromecó, Argentina
}

\section{Huellas fósiles de homínidos del Pleistoceno tardío en las playas de Claromecó, Argentina}

Carlos L. AZCUY ${ }^{1}$, Hugo A. CARRIZO², Eduardo P. TONNI ${ }^{3}$, Héctor PANARELLO ${ }^{4}$, Cecilia R. AMENÁBAR ${ }^{1}$

1 Departamento de Ciencias Geológicas, Facultad de Ciencias Exactas y Naturales, Universidad de Buenos Aires. Intendente Güiraldes 2160, Ciudad Universitaria, (C1428EGA) Ciudad Autónoma de Buenos Aires, Argentina. azcuycarlos@gmail.com, amenabar@gl.fcen.uba.ar

2 Instituto de Paleontología y Sedimentología, Sección Paleobotánica, Fundación Miguel Lillo. Miguel Lillo 251, (T4000JFE) San Miguel de Tucumán, Argentina. hugocarrizo5@yahoo.com.ar

3 División de Paleontología de Vertebrados, Universidad Nacional de la Plata. Av. 122 y 60, (B1926

ELN) La Plata, Buenos Aires, Argentina. eptonni@fcnym.unlp.edu.ar

4 Instituto de Geocronología y Geología Isotópica (INGEIS). Intendente Güiraldes 2160, Ciudad Universitaria, (C1428EGA) Ciudad Autónoma de Buenos Aires, Argentina. hectorpanarello@gmail. com

\begin{abstract}
Fossil ichnites of hominids found in Argentina are identified and described. The age of the sediments was determined using radiocarbon dating, by Uranium, OSL and paleomagnetic signatures of the sediments, along with an analysis of the associated megammalian tracks and their fossil bones. We conclude that the fossil ichnites dated about $30 \mathrm{ka}$ BP.
\end{abstract}

Keywords - Fossil ichnites, hominid, megamammals, Argentina.

\section{RESUMEN}

Se identifican y describen las icnitas fósiles de homínidos encontrados en la Argentina. La edad de los sedimentos se determinó utilizando la datación por radiocarbono, mediante Uranio, OSL y características paleomagnéticas de los sedimentos, junto

Ref. bibliográfica: Azcuy, C. L.; Carrizo, H. A.; Tonni, E. P.; Panarello, H.; Amenábar, C. R. 2021. "Late Pleistocene fossil hominid tracks on the beaches of Claromecó, Argentina". Acta Geológica Lilloana 33 (2): 43-57. doi: https://doi.org/10.30550/j.agl/2021.33.2/2021-08-03

- Recibido: 24 de noviembre 2020 - Aceptado: 3 de agosto 2021

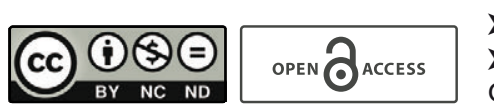

- URL de la revista: http://actageologica.lillo.org.ar

- Esta obra está bajo una Licencia Creative Commons Atribución - No Comercial - Sin Obra Derivada 4.0 Internacional. 
con el estudio de las huellas de los megamamíferos asociados y sus huesos fósiles. Concluimos que las icnitas fósiles de homínidos datan alrededor de los $30 \mathrm{ka} \mathrm{BP}$.

Palabras clave - Icnitas fósiles, homínidos, megamamíferos, Argentina.

\section{INTRODUCTION}

Hominid tracks discovered at The Caracolero of Claromecó Village, Buenos Aires province, Argentina, have been known for a decade. As a consequence of their discovery, we conducted a research project focused on their study, integrating different specialties of geology and paleontology. A research program was established and carried out in the successive years 2011 to 2019 and a synthesis of this project is presented here.

\section{MATERIAL AND METHODS}

The "Las Patas" ichno-paleontological site ( $38^{\circ} 522$ 35.2" S and $60^{\circ} 10242.5^{\prime}$ " W, 1 meter above sea level) is located in the southwest of Claromecó Village (Municipality of Tres Arroyos), in a place known as The Caracolero. It is part of the marine abrasion platform running for several dozen kilometers between the localities of Reta and Orense, Buenos Aires province, Argentina (Figure 1A and 1B).

The marine abrasion platform consists of two clearly visible elements, mainly in the Lighthouse profile on the upper beach: $a$ ) light brown continental sediments corresponding to the "Pampeano" period (Ameghino 1889, 1908), and $b$ ) overlapping marine deposits attributed to the "Belgranense" period (Frenguelli, 1928). Due to the characteristics of the Atlantic coast, where marine, wind and fluvial processes (López and Marcomini, 2011) are continuously affecting the geomorphology, plus human activity, the whole sequence is not preserved along the Claromecó coast. The best-preserved outcrop on the coast is near the lighthouse of the Claromecó Village, where we measured a stratigraphic section, called here the Lighthouse profile.

Unit B of the profile corresponds to the "Pampeano" continental period, and units C and D to the "Belgranense" period (Figure 2). The fossil hominid tracks were found about $14 \mathrm{~km}$ WSW of Claromecó (Azcuy et al. 2011a, b, c) on the marine abrasion platform of the lower beach in a wackestone plain. It is important to point out that continuity of the lower beach is clearly recognized between the wackestone present in the Lighthouse profile, which is $\sim 2-3 \mathrm{~m}$ above the marine stratigraphic levels and the base of The Caracolero, where the fossil hominid ichnites are found (Figures $1 \mathrm{~B}$ and $2 \mathrm{~B}$ ).

The fossil hominid ichnites are associated with Lestodon sp. ichnites that were found in the shoal, within the same rock unit, about $40 \mathrm{~cm}$ away from each other (Figure 3). Furthermore, Megatherium sp. bone remains (tibia and fibula) and plates and caudal tube of Glyptodon spp. were collected about $150 \mathrm{~m}$ westwards on the marine abrasion platform. Here, we follow the criteria of Lockley et al. (2016) and we use the term hominin in reference to the Hominini tribe. 

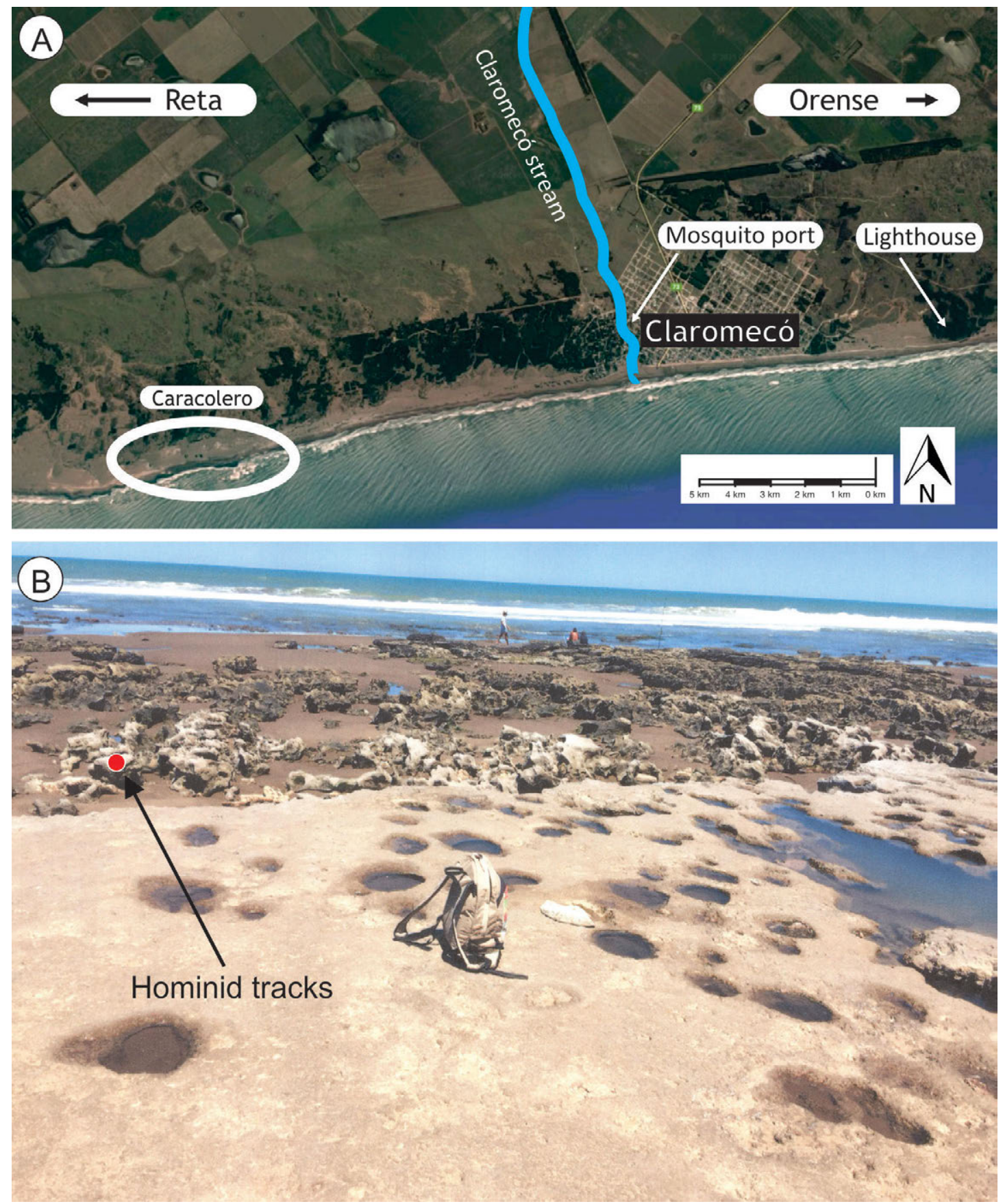

Figure 1. A) General view of the Claromecó Village and The Caracolero site, $14 \mathrm{~km}$ to the west. B) General view of The Caracolero's partially destroyed marine abrasion platform where numerous megamammal ichnites have been found.

The site was dated employing four different dating techniques: two ${ }^{14} \mathrm{C}$, two OSL (optically stimulated luminescence), one AMS (Accelerator mass spectrometry), and one U/Th (Uranium-thorium dating). The ${ }^{14} \mathrm{C}$ and AMS techniques were performed at the Instituto de Geocronología y Geología Isotópica (INGEIS-CONICETUBA), Buenos Aires, Argentina. OSL was performed in the Activation Laboratory LTD, Ontario, Canada. The U/Th data on Tegula patagonica d'Orbigny gastropod shells published by Isla et al. (2000) was obtained from the Laboratory CSIR, Preto- 


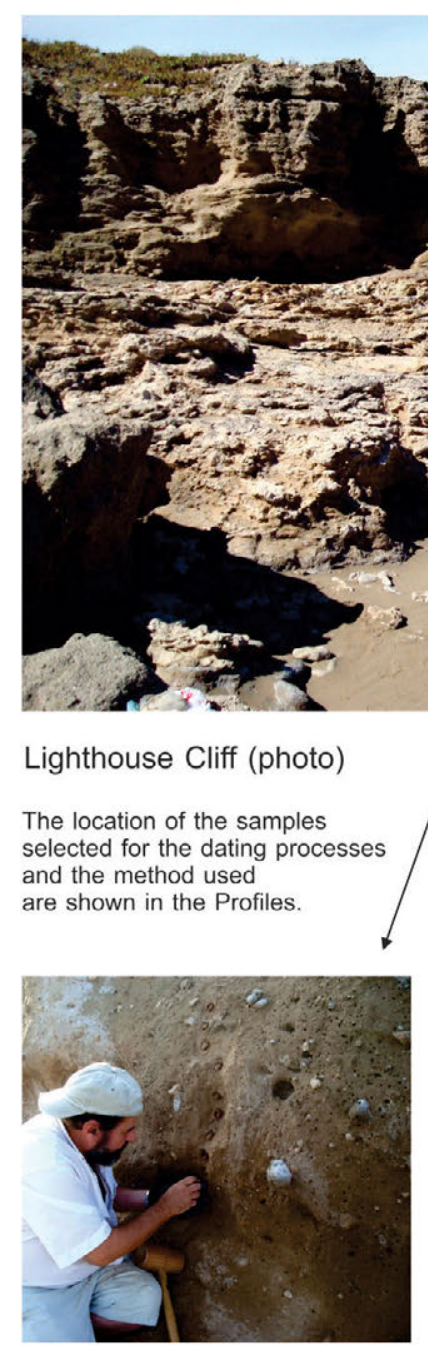

Samples for paleomagnetism

\section{Lithofacies code}

Gt: trogh cross-bedded gravel Gm: massive gravel

Gh: crudely bedded gravel

St: trough cross-bedded sand

Ss: chanel infilling sand and grave

Fr: massive silt and mud, toots, bioturbation

Cf: groundwater calcrete

Wb: diagenetic wackestone

References

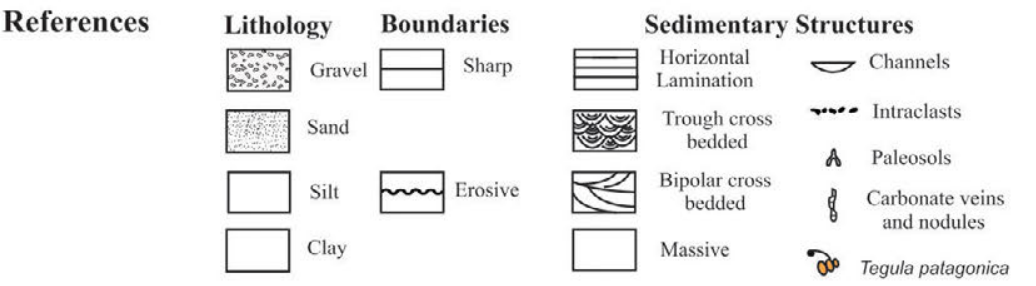

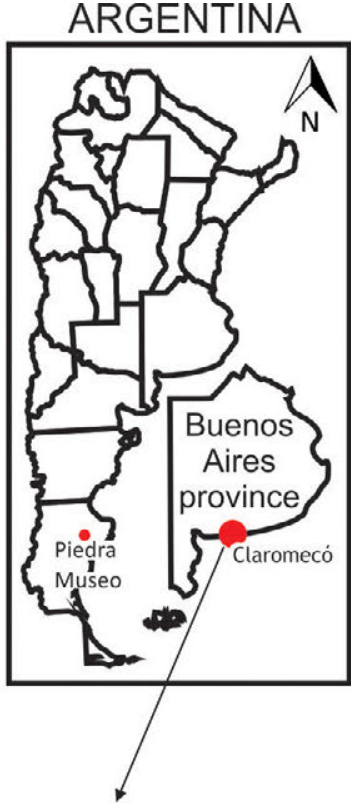

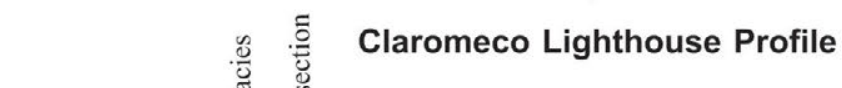

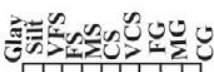

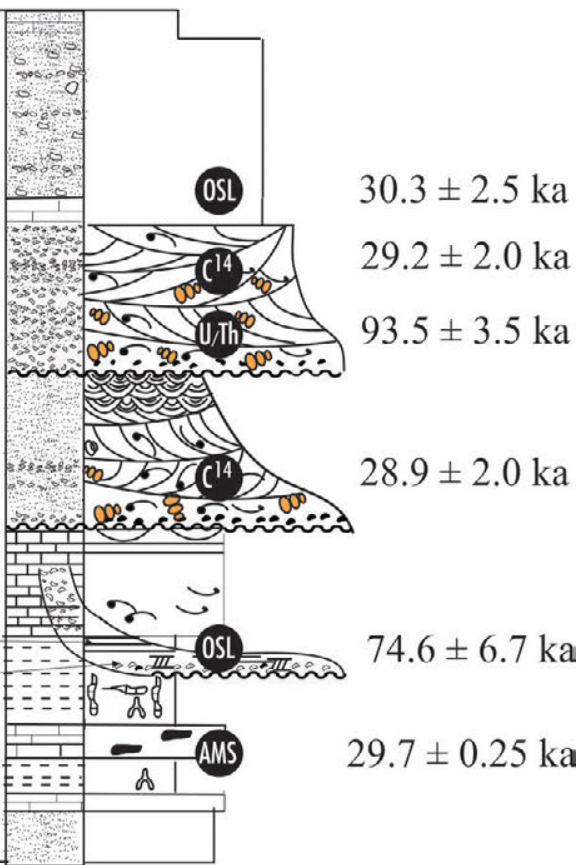

Modified from Tofalo et al. 2014

Figure 2. A) Location map of Claromecó Village, Buenos Aires province, Argentina. Photograph of the Lighthouse Cliff (in the left) where the stratigraphic profile was measured. Profile with the location of the samples selected for the dating analysis. 

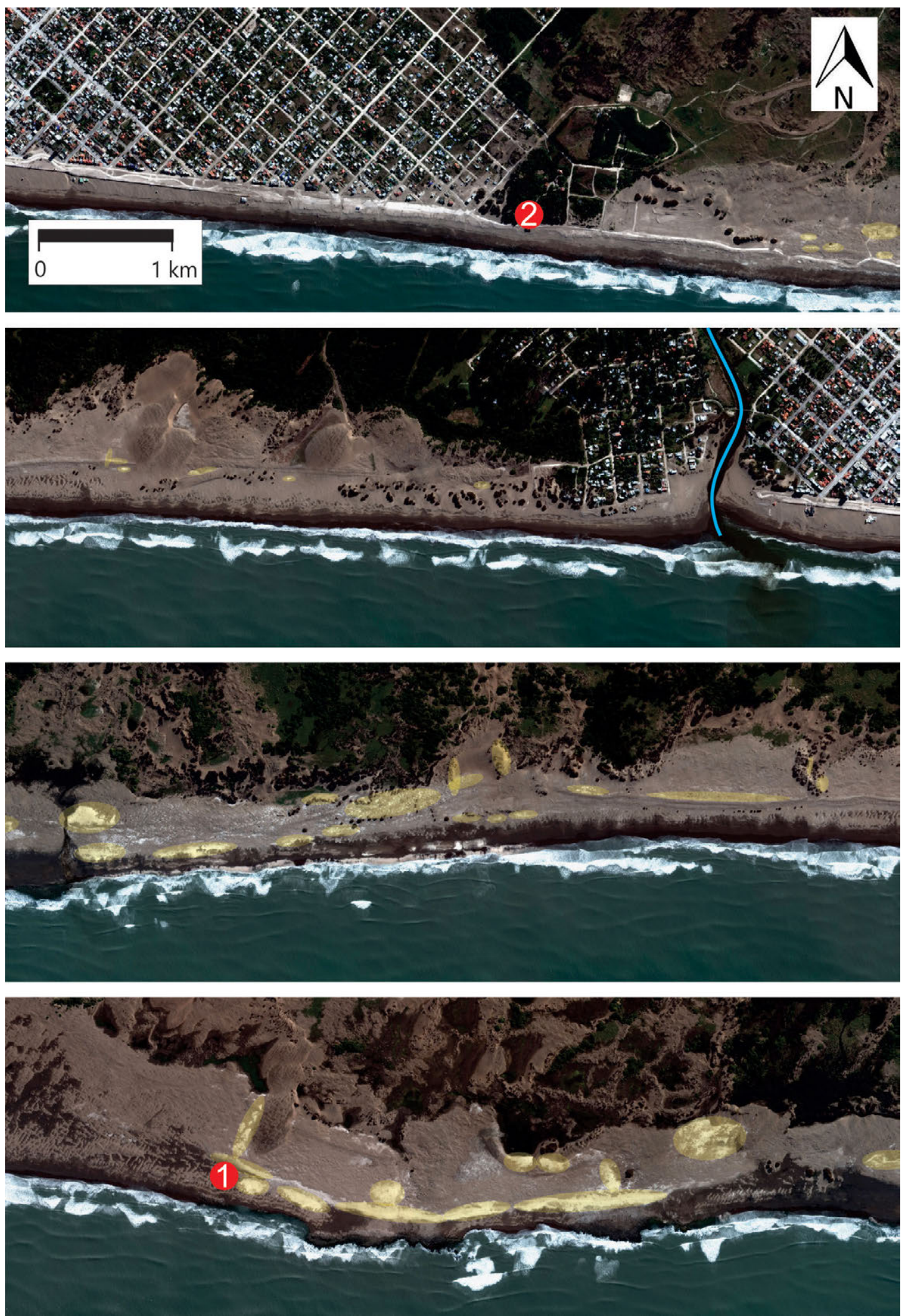

Figure 2. B) Correlation of the wackestone plates (highlighted in yellow) along the beach of Claromecó Village. Note the correlation between the wackestone of the Claromecó Lighthouse (2), in the right, and those that contain the hominin tracks in The Caracolero (1), in the left. 


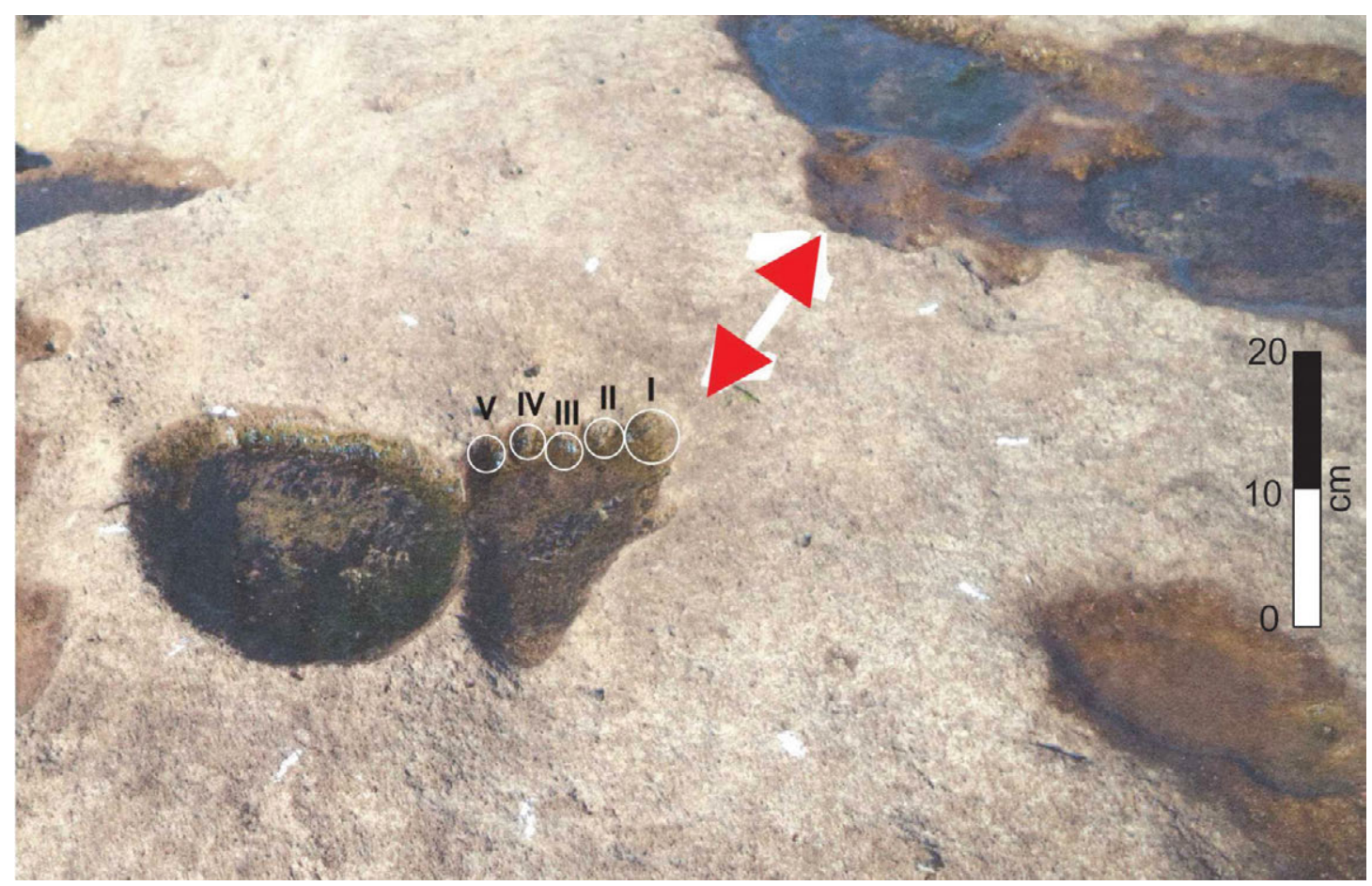

Figure 3. Rock with the hominid track (digits I to V) and with the Lestodon ichnite, separated by $40 \mathrm{~cm}$, in The Caracolero site.

Table 1. A) Dating analysis applied on the Lighthouse and The Caracolero profiles, Buenos Aires province, Argentina.

\begin{tabular}{|c|c|c|c|c|c|c|}
\hline Method & ${ }^{14} \mathrm{C}$ & ${ }^{14} \mathrm{C}$ & U/Th & OSL & OSL & AMS \\
\hline Unit & U-D & U-D & U-D & U-B & U-E & U-B \\
\hline Locality & $\begin{array}{l}\text { Lighthouse } \\
\text { Claromecó }\end{array}$ & $\begin{array}{l}\text { Lighthouse } \\
\text { Claromecó }\end{array}$ & $\begin{array}{l}\text { Lighthouse } \\
\text { Claromecó }\end{array}$ & $\begin{array}{l}\text { Lighthouse } \\
\text { Claromecó }\end{array}$ & $\begin{array}{l}\text { Lighthouse } \\
\text { Claromecó }\end{array}$ & $\begin{array}{c}\text { The Caracolero } \\
\text { profile }\end{array}$ \\
\hline Age results & $29.2 \pm 2 \mathrm{Ka}$ & $28.9 \pm 2 \mathrm{Ka}$ & $93.5 \pm 3.5 \mathrm{Ka}$ & $74.6 \pm 6.7 \mathrm{Ka}$ & $30.3 \pm 2.5 \mathrm{Ka}$ & $29.7 \pm 0.25 \mathrm{Ka}$ \\
\hline Authors & $\begin{array}{l}\text { Azcuy et al. } \\
\text { (2011a) }\end{array}$ & $\begin{array}{l}\text { Azcuy et al. } \\
\text { (2011a) }\end{array}$ & $\begin{array}{l}\text { Isla et al. } \\
(2000)\end{array}$ & $\begin{array}{c}\text { Tofalo et al. } \\
\text { (2017) }\end{array}$ & $\begin{array}{c}\text { Tofalo et al. } \\
\text { (2014) }\end{array}$ & $\begin{array}{c}\text { Azcuy et al. } \\
\text { (2011b) }\end{array}$ \\
\hline $\begin{array}{l}\text { Laboratory } \\
\text { name }\end{array}$ & $\begin{array}{l}\text { INGEIS, } \\
\text { Argentina }\end{array}$ & $\begin{array}{l}\text { INGEIS, } \\
\text { Argentina }\end{array}$ & $\begin{array}{l}\text { CSIR, Pretoria, } \\
\text { South África }\end{array}$ & $\begin{array}{l}\text { Activation } \\
\text { Laboratory } \\
\text { LTD, Ontario, } \\
\text { Canada }\end{array}$ & $\begin{array}{l}\text { Activation } \\
\text { Laboratory } \\
\text { LTD, Ontario, } \\
\text { Canada }\end{array}$ & $\begin{array}{l}\text { INGEIS, } \\
\text { Argentina }\end{array}$ \\
\hline
\end{tabular}

Table 1. B) Other early published dates from South and North America.

\begin{tabular}{|c|c|c|c|c|c|c|c|}
\hline Country & USA & Mexico & Brazil & Uruguay & Chile & Chile & Argentina \\
\hline Locality & California & Valsequillo & Pedra Furada & $\begin{array}{c}\text { Arroyo } \\
\text { Vizcaino }\end{array}$ & Monte Verde & Monte Verde & $\begin{array}{l}\text { Piedra } \\
\text { Museo }\end{array}$ \\
\hline Age results & $\begin{array}{c}130.7 \pm 9.4 \\
\text { Ка }\end{array}$ & $40 \mathrm{Ka}$ & $\begin{array}{c}41.3-47.2 \\
\mathrm{Ka}\end{array}$ & $28-29 \mathrm{Ka}$ & $\begin{array}{c}13.9-14.2 \\
\mathrm{Ka}\end{array}$ & $33 \mathrm{Ka}$ & $12,8-9,2 \mathrm{ka}$ \\
\hline Methods & ${ }^{230} \mathrm{Th} / \mathrm{U}$ & OSL & ${ }^{14} \mathrm{C}$ & ${ }^{14} \mathrm{C}$ & ${ }^{14} \mathrm{C}$ & ${ }^{14} \mathrm{C}$ & ${ }^{14} \mathrm{C}$ \\
\hline Authors & $\begin{array}{l}\text { Holen et al. } \\
\quad(2017)\end{array}$ & $\begin{array}{l}\text { González et } \\
\text { al. (2006) }\end{array}$ & $\begin{array}{l}\text { Santos et al. } \\
(2003)\end{array}$ & $\begin{array}{c}\text { Fariña and } \\
\text { Castilla } \\
(2007)\end{array}$ & $\begin{array}{l}\text { Dillehay } \\
\text { et al. } \\
\text { (2008) }\end{array}$ & $\begin{array}{l}\text { Dillehay } \\
\text { and Collins } \\
(1988)\end{array}$ & $\begin{array}{l}\text { Miotti and } \\
\text { Salemme } \\
(2004)\end{array}$ \\
\hline
\end{tabular}


ria, South Africa, while the analysis of Tegula patagonica d'Orbigny presented in this study, was performed by ${ }^{14} \mathrm{C}$ dating in the INGEIS, Argentina. The result yielded a range of different ages from $\sim 30 \mathrm{ka}$ to $93.5 \mathrm{ka}$ (Table 1A).

The counterpart of the footprint III is deposited in the "Regional Museum Aníbal Paz" of Claromecó Village, Buenos Aires Province, Argentina. It consists of a footprint cast that was donated by one of the authors (C.L.A.).

The tibia and fibula of Megatherium are under temporary shelter in Claromecó Village until the expansion of the museum, which is under construction, is completed. Some of the fossils are in the process of cleaning and will be donated to the museum.

\title{
SYSTEMATIC ICHNOLOGY
}

\author{
Ichnogenus Hominipes Kim et al., 2008 \\ Hominipes cf. modernus Kim et al., 2008
}

Figures 4, 5

Description.- The trackway (Figure 4A) contains three footprints, extended in antero-posterior direction. The sizes are $157 \mathrm{~cm}$ long and $9.4 \mathrm{~cm}$ wide.

Footprint \#1 sizes are $18.7 \mathrm{~cm}$ long and $10.3 \mathrm{~cm}$ wide, the right foot step is 36 $\mathrm{cm}$ and stride length $71 \mathrm{~cm}$.

Footprint \#2 is partially preserved and somewhat deformed, step $65 \mathrm{~cm}$, stride length $128 \mathrm{~cm}$.

Footprint \#3 is the best preserved (Figures $4 \mathrm{~B}$ and 5) and is $21.5 \mathrm{~cm}$ long by $10.5 \mathrm{~cm}$ wide, left foot, with a mid-heel breadth of $6.3 \mathrm{~cm}$. It is a pentadactyl bipedal footprint where the five-digit footpad print is clearly identified (Figures 4B and 5).

The larger (digit I) print depth, as compared to the print depth of smaller digit II to V, seems to reflect the transfer of the bodyweight towards the other foot, as could be seen with the lifting of the digit I, implying a forward and downward force during footprint registration. This interpretation would explain the sinking of the fingernail, deformed and prominent, into the silt. Digit II is as long as digit I or slightly shorter. Digit III seems to be lower or flexed, partially resting on top of digit IV probably due to a foot malformation or uneven ground conditions. Digits IV and $\mathrm{V}$ are slightly shorter than digits I and II. Footprints \#1 and \#3 show slightly concave inner border regions reflecting the morphology of the pedal arch.

The fingerprints correspond to five toe pads separated by visible interdigital grooves. The digit I impression is prominent unlike the impression of the heel, which is poorly visible since the footprint corresponds to a hominin that is walking.

Remarks. - The abovementioned material shows slight differences with Hominipes modernus such as the tenuous heel mark and the different position of digit III (see above). The poor preservation of the heel prevents a specific assignment. 

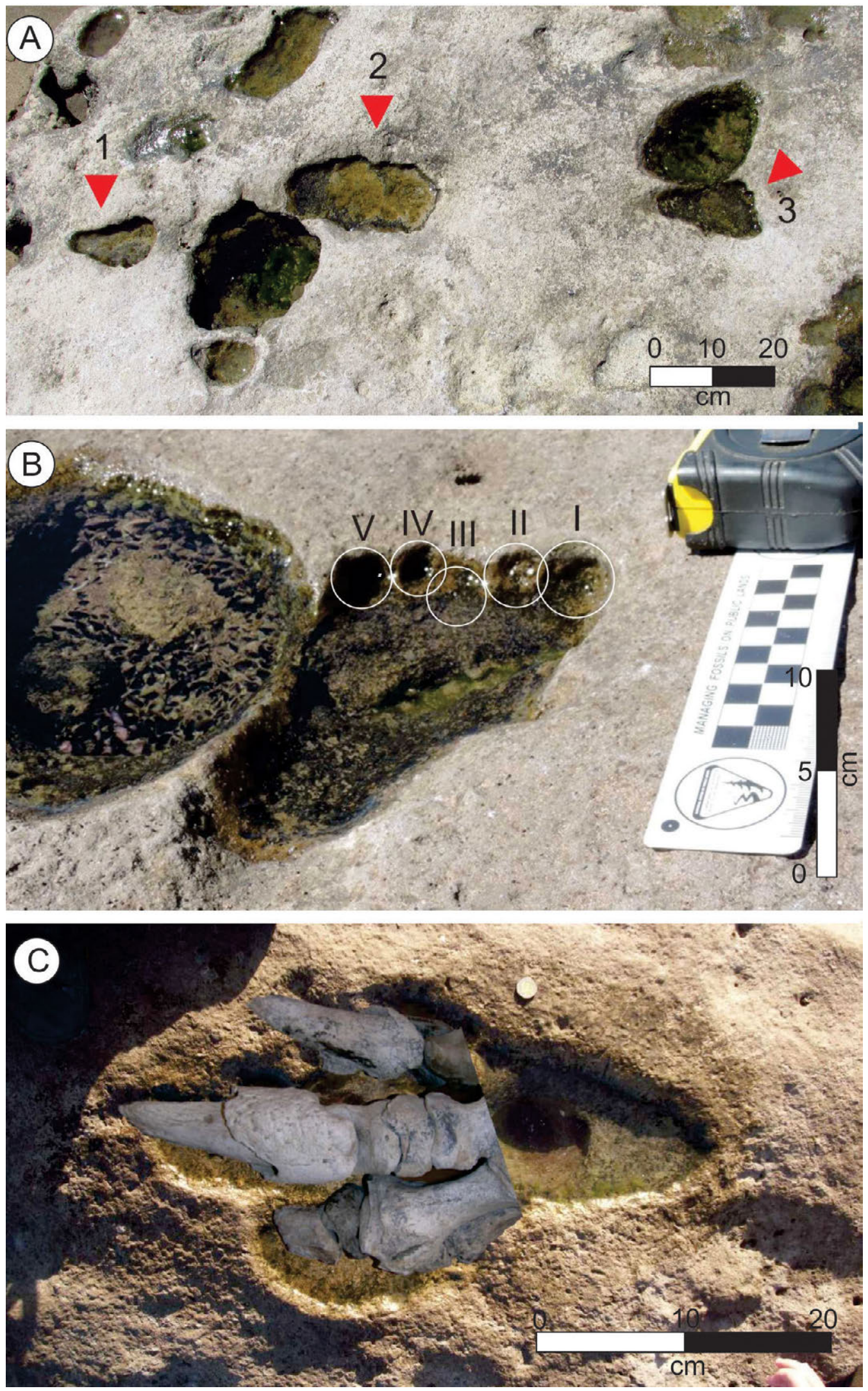

Figure 4. A) Trackway with three footprints (footprints \#1, \#2, and \#3) indicated by the red arrows. B) Detail of the right hominid track (footprint \#3) showing the five digits (I-V). C) Hominid track of photograph B next to the Lestodon ichnite. D) Lestodon ichnite showing the three major tarsal bones overlaid on a scale photograph of a virtual reconstruction of the foot (after Clavijo García, 2018). 

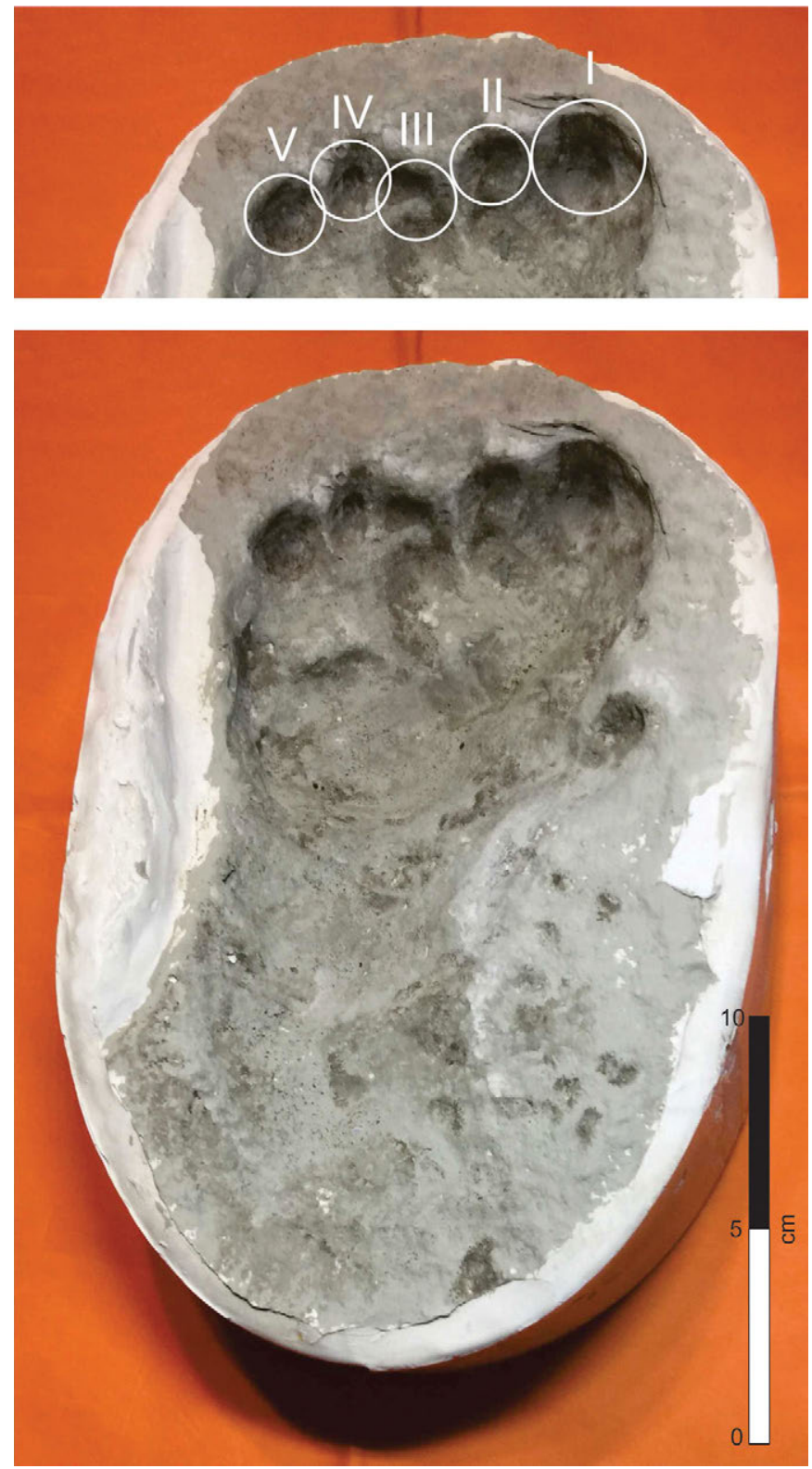

Figure 5. The counterpart of the fossil of Figure 4.B showing the digit I claw embedded in the silt, the position of digit III, and the visible interdigital grooves separating the digits.

Comments.- It is worth noting that some sedimentologists and petrologists have disputed the validity of the fossil ichnites from "Las Patas". Bonomo and Blasi (2016) assured to have seen only four finger tracks and they attributed all the traces to erosion microreliefs called "pans" and "pits". Digit III has not been observed by the above-mentioned authors and the preservation of tracks on the upper beach is remarkably different from that of the lower beach, which is subject to ongoing chemical and physical alteration. However, based on our evaluation, we observed digit III in the track (footprint \#3), completing an imprint with five fingers, which is enough evidence to consider it as a hominin track as it is shown in Figures $4 \mathrm{~B}$ and 5 (mold and counterpart). 


\section{DISCUSSION}

\section{Megamammal ichnites and bones}

The hominin footprints are $40 \mathrm{~cm}$ away from the Lestodon sp. ichnite, on the same rock unit (Figures 3 and 4C). The latter has the following dimensions: maximum length $69 \mathrm{~cm}$ with claw and $62.5 \mathrm{~cm}$ without claw, maximum breadth $32.5 \mathrm{~cm}$. Figures 4C-D show the Lestodon's three major tarsals, the longest one with a claw, overlaid on a scale photograph, with a morphological fit. About $150 \mathrm{~m}$ to the $\mathrm{W}$ and on the same stratigraphic level, a Megatherium sp. tibia and fibula were recovered (Figure 6A-B). This further proves that between 30 and $93.5 \mathrm{ka}$ ago, the hominins, the Lestodon sp. and Megaterium sp. were contemporaneous (Table 1A). The paleontological records provided by the megamammals Lestodon sp. and Megatherium sp. indicate that both taxa were present throughout the late Pleistocene (between 126 ka and $11 \mathrm{ka} \mathrm{BP}$ ) integrating the Late Bonaerian-Lujanian mammal ages (Bayón et al., 2011; Cione et al., 2015).

\section{Dating analysis in Claromecó Village}

Two ${ }^{14} \mathrm{C}$ data from the marine gastropod Tegula patagonica d'Orbigny, obtained from the conglomerate levels of unit $\mathrm{D}$ of the Lighthouse profile (Figure 2A), yielded an age of [29.2 $\pm 2 \mathrm{ka}]$ and [28.9 $\pm 2 \mathrm{ka} \mathrm{BP}$ ], respectively. Isla et al. (2000) performed a U/Th analysis from Tegula patagonica d'Orbigny in sandstones and conglomerates from Claromecó cliffs that yielded an age of [ $93.5 \mathrm{ka} \mathrm{BP} \pm 3.5 \mathrm{ka}$ ] (Table 1A), supporting the worldwide accepted Sangamon Interglacial (oxygen isotopic substage $5 \mathrm{e}, 120 \mathrm{ka}$ ). The stratigraphical range of this marine gastropod spans the middle Miocene ( $\sim 13 \mathrm{Ma})$ to the Holocene (del Río, 1989).

An OSL dating obtained from unit B yielded an age of [74.6 $\pm 6.7 \mathrm{ka} \mathrm{BP}]$ (Tofalo et al., 2014, 2017; Vizán et al., 2015). An AMS dating on a Megatherium tibia and fibula found in The Caracolero (approximately $150 \mathrm{~m}$ from the footprints) yielded an age of $[29.7 \pm 0.25 \mathrm{ka} \mathrm{BP}]$.

\section{Other dating analysis in America}

The results presented here broadens the discussion about the age of the above-mentioned hominin tracks and other known hominin ichnites associated with megamammal bones (Lockley et al. 2016). Previous early dates of hominins in South and North America include (Table 1B): $\boldsymbol{A}$ ) The artifacts and rock art in Pedra Furada (Brazil) with radiocarbon ages between [32-17 ka BP] (Guidon and Delibrias, 1986); B) Human footprints and stone tools in Monte Verde II (Chile), with ages around [14 ka BP] (Dillehay et al., 2008); C) The Lestodon bones (clavicle and ribs) with cut marks made by humans in Arroyo Vizcaíno (Uruguay), with a ${ }^{14} \mathrm{C}$ age of $28-29$ ka BP] (Fariña and Castilla, 2007); D) Two Argentine localities: 1) Piedra Museo, in the Santa Cruz province, in a site occupied by the earliest hunter-gatherer populations with faunal remains such as Hippidion saldiasi, an American extinct house 

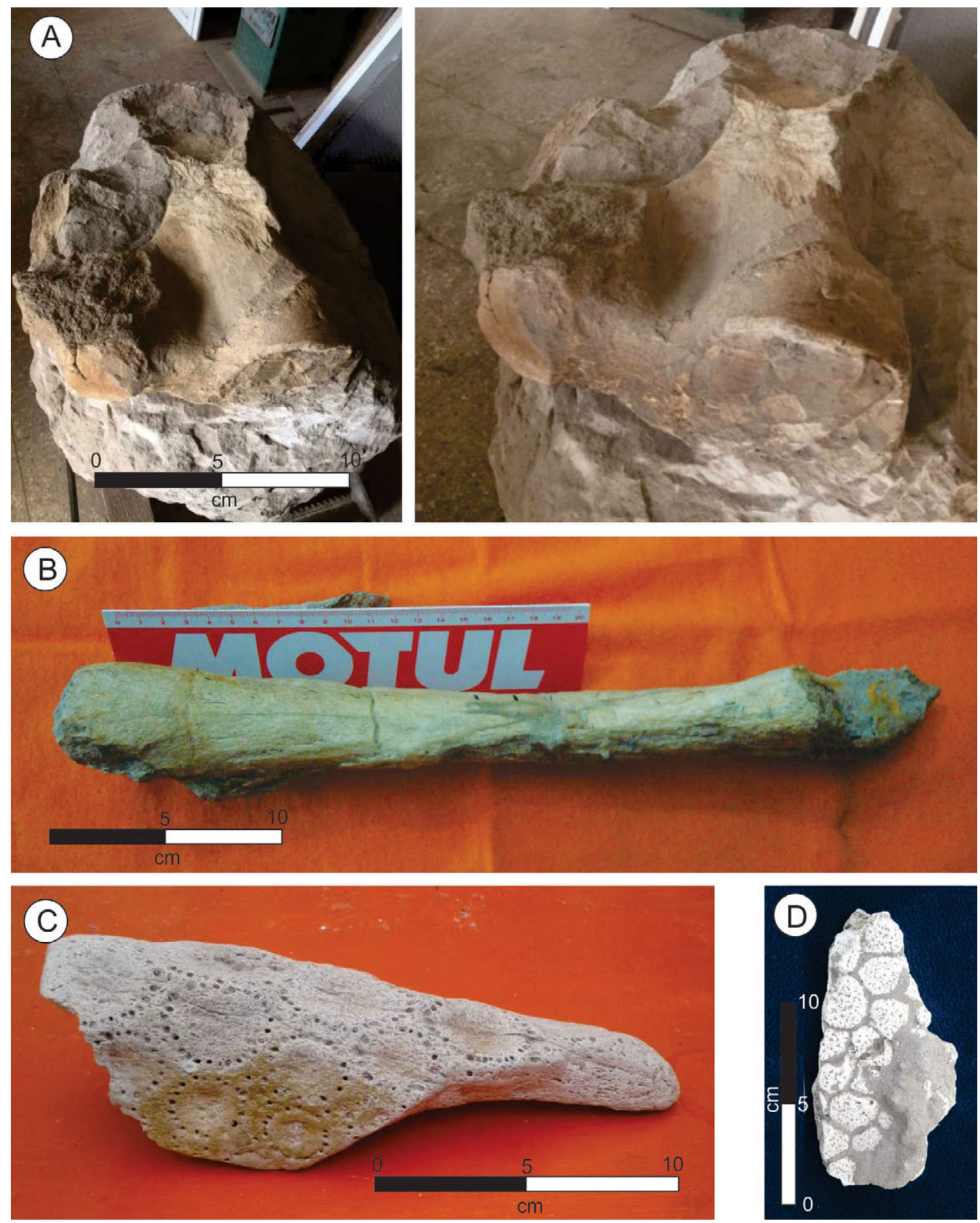

Figure 6. Megatherium and Glyptodon bone remains. A) Tibia of the Megatherium sp. B) Fibula of the Megatherium sp. C) Caudal tube of Glyptodon sp. D) Fragmented caudal tube of Glyptodon reticulatus.

whose bones showed cut marks which are indications of human butchering, dated by AMS [12.8-9.2 ka BP] (Miotti and Salemme, 2004) and 2) Claromecó, in the Buenos Aires province (the present work) and $\boldsymbol{E}$ ) The discovery from California, USA, of the Cerruti Mastodon bones with evidence of human interaction of [130 ka BP] (Holen et al., 2017). 


\section{Discussion of paleomagnetic and sedimentological data}

A record of the Blake geomagnetic event is preserved in the stratigraphic section outcropping at Claromecó locality, Buenos Aires province, Argentina (Vizán et al., 2019). This allows the assignment of the sedimentary sequence to the Belgranense. This informal stratigraphic unit is composed of continental and marine deposits developed during the MIS 5e (Marine Isotopic Stage 5) interglacial. Different facies provided distinct paleomagnetic direction: reverse and/or oblique reverse remanent magnetic components were recorded in marine wackestones and pedogeneized loess.

Two upper facies of the section (deposits of a tidal channel and a carbonate mudstone) recorded direction with normal polarity. The section records multiple marine ingressions, the oldest corresponds to Unit $\mathrm{A}$ and the second to Units $\mathrm{C}$ and D. Paleosols, developed on loess sediments, are represented in Unit B. These four pulses correspond to four or five substages in which the Marine Isotopic Stage 5 is divided (Tofalo et al., 2014).

The profile has two stratigraphic discontinuities that are suggested by: a) the erosive base of the channel running over the paleosoils and calcretes (Tofalo et al., 2014), and b) the top of the marine deposits covered by new continental deposits (Figure 2, Unit-E). Both Isla et al. (2000) and Vizán et al. (2019) considered that these marine deposits would be close to $120 \mathrm{ka}$ old and would have been settled during the Marine Isotope Stage 5e.

Tofalo et al. (2017) suggested that the age yielded by the OSL dating [74.6 ka $\mathrm{BP}]$ is a minimum age since the magnetically studied deposits are over a stratigraphic discontinuity, and suggest that the oblique reverse polarity paleomagnetic directions could be attributed to the Blake Event (120 ka BP).

Considering the data shown in Table 1 and Figure 2A, we observe that six dating analyses were applied between Claromecó and The Caracolero using four different techniques: two ${ }^{14} \mathrm{C}$, two OSL, one U/Th, and one AMS. Four of them are convergent with an age of $\sim 30 \mathrm{ka}$. However, the ${ }^{14} \mathrm{C}$ ages would be close to the method reliability threshold; the OSL of Unit B (Figure 2A) would be over a stratigraphic discontinuity, and the U/Th would be considered a minimum age.

Taking into account the biostratigraphic ranges of the invertebrates and megamammals, and the magnetostratigraphic and sedimentological data, we infer that both ages obtained in the Unit B and D of the Lighthouse profile (the oldest ones), would be minimum ages (see above), and we propose that the hominin tracks are close to $30 \mathrm{ka}$.

\section{CONCLUSIONS}

The paleontological evidence indicates that both the invertebrates and the megamammals could be older than the ${ }^{14} \mathrm{C}$ ages, which is likely to be around $30 \mathrm{ka}$ because the ${ }^{14} \mathrm{C}$ ages would be close to the method reliability threshold.

Finally, according to the paleontological data, the interpretation of the dating processes, and the information provided by the magnetostratigraphy and the sedi- 
mentology, we consider that the hominin tracks, the megamammal ichnites and bone remains would be closer to $30 \mathrm{ka}$ old.

\section{ACKNOWLEDGMENTS}

Special thanks to Dr. Gabriela Mangano for the critical reading of the manuscript, her selfless suggestions enriched the work. Thanks to Drs. Rita Tofalo and Haroldo Vizán for their collaboration in sedimentology and magnetostratigraphy, respectively. To Dr. Carlos Concheyro for providing the first description of the footprints. To Andrea Peresel for her English translation, to Dr. Eduardo Giordano and Mr. Carlos Bancur for their unconditional support throughout the fieldwork and collection of bone remains. Special thanks to Germán Azcuy for his assistance in the figures. The authors gratefully acknowledge the editor Dr. Ana Fogliata and the reviewers Dr. Claudia Muruaga, Dr. Guillermo Aceñolaza and Dr. Pablo Grosse for their comments and corrections that improved our manuscript. Finally, we would like to thank the "Regional Museum Aníbal Paz" of Claromecó Village, whose authorities have always collaborated with this research.

\section{REFERENCES}

Ameghino, F., 1889. Contribución al conocimiento de los mamíferos fósiles de la República Argentina. Actas de la Academia Nacional de Ciencias de la República Argentina en Córdoba, Actas 6: 253-256.

Ameghino, F., 1908. Las formaciones sedimentarias de la región del litoral de Mar del Plata y Chapadmalal. Museo Nacional Histórico Natural de Buenos Aires. Serie 3(10): 343-428.

Azcuy, C., Acevedo, D., Amenábar, C., Babot, J., Codignotto, J., Czrwonogora A., Fariña R., Krapovicas V., Panarello H., and Vizán H., 2011a. Observaciones Geológicas en el acantilado del faro de Claromecó. XVIII Congreso Geológico Argentino, Neuquén. Actas: 250-251.

Azcuy, C., Acevedo, D., Amenábar, C., Babot, J., Codignotto, J., Czrwonogora, A., Fariña, R., Krapovicas, V., Panarello, H. and Vizán, H., 2011b. Datos paleontológicos, huellas y petrografía en los alrededores del caracolero de Claromecó. XVIII Congreso Geológico Argentino, Neuquén. Actas: 252-253.

Azcuy, C., Acevedo, D., Amenábar, C., Babot, J., Codignotto, J., Czrwonogora, A., Fariña, R., Krapovicas, V., Panarello, H. and Vizán, H., 2011c. Radimetría, paleomagnetismo y registros de antiguos pobladores humanos en las inmediaciones de Claromecó: comparación con otros hallazgos de presencia humana en América. XVIII Congreso Geológico Argentino, Neuquén. Actas: 254-255.

Bayón, C., Manera, T., Politis, G. and Aramayo, S., 2011. Following the Tracks of the First South Americans. Evo Edu Outreach 4: 205-217. https://doi.org/10.1007/ s12052-011-0335-4 
Bonomo, M. and Blasi, A., 2016. Microrrelieve costero vs. Icnitas humanas en la localidad El Caracolero (Claromecó, Argentina). Antipoda, Revista de Antropología y Arqueología, 25: 169/190. https://doi.org/10.7440/antipoda25.2016.08

Cione A. L., Gasparini G.M., Soibelzon E., Soibelzon L. B. and Tonni E. P. 2015. The Great American Biotic Interchange. A South American Perspective. (Eds. A.L. Cione, G. M. Gasparini, E. Soibelzon, L. H. Soibelzon and E. P. Tonni). Springer Briefs in Earth System Sciences: 1/95. ISBN 978-94-017-9792-4.

Clavijo García, L. 2018. Anatomía del pie de Lestodon armatus (Xenarthra, Folivora). Graduate Thesis, Universidad de la República (Uruguay), Facultad de Ciencias. $42 \mathrm{pp}$.

del Río, C.J. 1989. Bioestratigrafía y paleontología de los bivalvos y gastrópodos de la Formación Puerto Madryn (Mioceno medio marino), de Península Valdés y alrededores de Puerto Madryn, Provincia de Chubut, República Argentina. PhD Thesis, Universidad de Buenos Aires. 679 pp.

Dillehay, T.D. and Collins, M.B. 1988. Early cultural evidence from Monte Verde in Chile. Nature 332: 150-152. https://doi.org/10.1038/332150a0

Dillehay, T.D., Ramírez, C., Pino, M., Collins, M.B., Rossen, J. and Pino Navarro J.D. 2008. Monte Verde seaweed, Food, Medicine, and the peopling of South America. Science 320 (5877): 784-786. https://doi.org/10.1126/science.1156533

Frenguelli, J., 1928. Observaciones geológicas en la región costanera sur de la provincia de Buenos Aires. Anales de la Facultad de Ciencias de la Educación 2: 1-145.

Fariña, R.A. and Castilla, R. 2007. Earliest evidence for human-megafauna interaction in the Americas. In: Human and faunal relationships reviewed: an archaeozoological approach (Eds. E. Corona-M. and J. Arroyo-Cabrales). Oxford, UK. Archaeopress. 31-34.

González, S., Huddart, D., Bennet, M.R. and González-Huesca, A. 2006. Human footprints in Central Mexico older than 40,000 years. Quaternary Science Reviews. 25(3): 201-222. https://doi.org/10.1016/j.quascirev.2005.10.004

Guidon, N. and Delibrias, G. 1986. Carbon-14 dates point to man in the Americas 32,000 years ago. Nature 321:769-771. https://doi.org/10.1038/321769a0

Holen, S.R., Demére, T.A., Fisher, D.C., Fullagar, R., Paces, J.B., Jefferson, G.T., Beeton, J.M., Cerutti, R.A., Rountrey, A.N., Vescera, L. and Holen K.A. 2017. A 130,000-year-old archaeological site in southern California, USA. Nature 544: 479-483. http://dx.doi.org/10.1038/nature22065

Isla, F.I., Rutter, N.W., Schnack, E.J. y Zárate, M.A. 2000. La transgresión Belgranense en Buenos Aires. Una revisión a cien años de su definición. Revista Cuaternario y Ciencias Ambientales, Asociación Geológica Argentina 1: 3-14.

Kim J.Y., Kim Kyung Soo, Lockley M.G. and Matthews Neffra 2008. Hominid Ichnotaxonomy: An Exploration of a Neglected Discipline. Ichnos 15: 126-139. DOI: $10.1080 / 10420940802467868$

Lockley, M., Meldrum, J. and Kim J.Y. 2016. Major Events in Hominin Evolution. (Mángano, M.G. and Buatois, L.A.: Eds. The trace fossil record of major evolutionary changes, vol. 2: Mesozoic and Cenozoic. Topics in Geobiology 40: 411-448. Springer. ISBN 978-94-017-9597-5. 
López, R. and Marcomini, S. 2011. Problemática de los ambientes costeros. Sur de Brasil, Uruguay y Argentina. Editorial Croquis. Buenos Aires, Argentina. 108 pp.

Miotti, L. and Salemme, M. 2004. Poblamiento, movilidad y territorios entre las sociedades cazadoras-recolectoras de Patagonia. Complutum 15: 177-206.

Santos, G.M. Bird, M.I. Parenti, F. Fifield, L.K. Guidon, N. and Hausladen, P.A. 2003. A revised chronology of the lowest occupation layer of Pedra Furada Rock Shelter, Piauýì, Brazil: the Pleistocene peopling of the Americas. Quaternary Science Reviews 22 (21-22): 2303-2310. https://doi.org/10.1016/S02773791(03)00205-1

Tofalo, O.R., Orgeira, M, J., Azcuy, C.L. and Vizán, H. 2014. El perfil Faro Claromecó: nuevas dataciones y evidencias sedimento-pedológicas en una sucesión pleistocena. XIX Congreso Geológico Argentino, S13: 5/6.

Tofalo, R., Orgeira, M.J., Castro, L., Vizan, H. and Azcuy, C., 2017. Variaciones paleoclimáticas durante el Cenozoico tardío en el sudeste de la provincia de Buenos Aires. Revista de la Asociación Geológica Argentina 74(4): 485-496.

Vizán, H., Tófalo, O.R. Orgeira, M.J. and Panarello, H. 2015. El perfil Faro Claromecó: Dataciones y estudio paleomagnético en una sucesión pleistocena VI Congreso Argentino de Cuaternario y Geomorfología, Ushuaia, 127.

Vizán, H., Azcuy, C.L., Tofalo, R.O., Geuna, S., Amenábar, C., Orgeira, M.J., Renda, E.M, Braña Carreño, C., Panarello, H. and Castro, L. 2019. The Blake Geomagnetic Field Event recorded in a sequence of marine and continental facies outcropping in the coast of Buenos Aires province, Argentine. Fournal of South American Earth Sciences 92: 1-17. https://doi.org/10.1016/j.jsames.2019.03.026 